\title{
Metal Recovery from Aqueous Solutions
}

\author{
C. Ascensão, L. Ciríaco, M.J. Pacheco, A. Lopes \\ UMTP Department of Chemistry, University of Beira Interior, 6201-001, Covilhã, Portugal
}

Received 5 January 2011; accepted 3 March 2011

\begin{abstract}
Metal recovery by reduction of metal ions present in model solutions, containing one or more heavy metals, was performed. To prepare the model solutions, sulfates and/or chlorides of $\mathrm{Cu}(\mathrm{II}), \mathrm{Cd}(\mathrm{II}), \mathrm{Pb}(\mathrm{II})$ and $\mathrm{Zn}$ (II) were used, at $\mathrm{pH}$ 3.5. Assays were run in a one or two compartments cell, at different applied potentials, using a steel plate as cathode, a platinum plate as anode and an $\mathrm{Ag} / \mathrm{AgCl}, \mathrm{KCl}$ sat as reference electrode. The metal recovery yield was determined by atomic absorption spectroscopy. The phases corresponding to the metallic deposits were identified by X-ray diffraction.

For the solutions containing just one metal ion, the best metal recoveries and the corresponding applied potentials, obtained in a one cell compartment, were the following: $\mathrm{Cu}^{2+} 99 \%$ at $\mathrm{E}=-100 \mathrm{mV} ; \mathrm{Pb}^{2+} 99 \%$ at $\mathrm{E}=-800 \mathrm{mV} ; \mathrm{Cd}^{2+} 93 \%$ at $\mathrm{E}=-$ $900 \mathrm{mV}$; and $\mathrm{Zn}^{2+} 38 \%$ at $\mathrm{E}=-1300 \mathrm{mV}$.

The metal removals from the mixed solution of four heavy metals, after 4 consecutive chronoamperometries, performed in a one compartment cell, at the best applied potentials determined with the solutions containing only one metal ion, were the following: $\mathrm{Cu}^{2+} 99 \% ; \mathrm{Pb}^{2+} 68 \% ; \mathrm{Cd}^{2+} 92 \%$; and $\mathrm{Zn}^{2+} 10 \%$.
\end{abstract}

Keywords: metal recovery; copper; lead; cadmium; zinc.

\section{Introduction}

Heavy metals are one of the most dangerous classes of pollutants [1,2]. There are several methods for their separation and recovery, some of them using a combination of various techniques, such as membrane processes, electrolysis or precipitation, to recover metal ions in the metallic state or as oxides or hydroxides, with the possibility of being reused later, thereby recovering their market value $[3,4]$.

The application of electrochemical techniques in the environmental remediation is increasing because, besides being very versatile, they can be applied in the removal of polluting solids, liquids and gases. The recovery of heavy metals from aqueous solutions is one of the examples of the use of electrochemical

\footnotetext{
* Corresponding author. E-mail address: lciriaco@ubi.pt
} 
methods with environmental purposes [5-9]. In fact, several metal ions in solution can be recovered in the metallic form by reduction at a cathode under specific conditions. Examples are silver and copper [5,8,10-15], whose economic value is significant, and cadmium, lead and nickel [6] used in common and car batteries, whose toxicity is high. The recovery of metals from $\mathrm{Ni}-\mathrm{Cd}$ batteries has also been intensively studied in the last decade [7,16-18]. In the case of lead, besides the reduction at the cathode, its oxidation can also take place at the anode, obtaining lead metallic and lead oxide (IV) [19], respectively, being both useful products. During the metal ion recovery from solution, cathodic side reactions can take place, like hydrogen evolution or reduction of the dissolved oxygen to form water, thus decreasing the current efficiency of the process.

Besides the recovery of isolated metal ions, several papers were also published in what concerns the recovery of metals from mixed solution [9,18,20,21].

In this paper, the deposition of several metals from aqueous solutions containing either a single metal ion or a mixture of metal ions is reported. Metal recoveries were performed under potentiostatic conditions from chloride or sulfate solutions containing $\mathrm{Cu}(\mathrm{II}), \mathrm{Pb}(\mathrm{II}), \mathrm{Cd}(\mathrm{II}), \mathrm{Zn}$ (II) as heavy metals.

\section{Experimental}

All reagents used in this study were analytical grade, from Sigma Aldrich, having purities higher than $99 \%$. The model solutions were aqueous solutions containing one or more metal salts and an electrolyte. The heavy metal salts used in the preparation of the model solutions were copper sulfate, cadmium sulfate, zinc sulfate and lead chloride, with concentrations of $10^{-2} \mathrm{~mol} \mathrm{~L}^{-1}$. This value was chosen since this is a common value for the concentration of heavy metals in some industrial effluents [5,21]. In the case of lead, a chloride salt was used instead of the sulphate, since sulfate salt has very low solubility. The electrolytes, $\mathrm{Na}_{2} \mathrm{SO}_{4}$ or $\mathrm{KCl}$, were chosen since they have a common anion with the metal salt and they were used with a concentration of $0.035 \mathrm{~mol} \mathrm{~L}^{-1} \cdot \mathrm{H}_{2} \mathrm{SO}_{4}$ or $\mathrm{HCl}$ solutions, $0.1 \mathrm{~mol} \mathrm{~L}^{-1}$, were used to correct the $\mathrm{pH}$ value to 3.5 [9].

In order to choose the potential values to run the assays of metal recovery from solution, by chronoamperometry, linear and cyclic voltammetries were run with the model solutions. Applied scanning rates ranged between 0.025 and $25 \mathrm{mV} \mathrm{s}^{-1}$. After the identification of the highest cathodic potential (HCP) that allowed the recovery of the metal from solution, chronoamperometries were performed with the model solutions containing one or the four metal salts. In the former case, chronoamperometry was run for $3 \mathrm{~h}$ at several cathodic applied potentials, lower than HCP determined for the metal, and the metal ion yield recovery was calculated; in the later case, four chronoamperometries were successively run, with duration of $3 \mathrm{~h}$ each, at the different applied potentials determined in the first part of the study as those who allowed best recovery yields for every metal ion.

Chronoamperometries were performed, at room temperature, with stirring. The total volume of solution used in the experimental assays of metal recovery was $200 \mathrm{~mL}$, for tests run in a one compartment cell. This cell had four electrodes 
connected to the potentiostat/galvanostat: an $\mathrm{Ag} / \mathrm{AgCl}, \mathrm{KCl}_{\text {sat }}$ electrode as reference electrode; a steel plate with $10 \mathrm{~cm}^{2}$ (both sides) as working electrode; two square platinum plates, $12.5 \mathrm{~cm}^{2}$ each, as auxiliary electrodes, placed on each side of the steel plate.

In the case of lead chloride, an electrochemical cell with two compartments was also used. One of the compartments contained $150 \mathrm{~mL}$ of metal salt solution in the electrolyte, acidified to 3.5, the working electrode and the reference electrode. The other compartment had $150 \mathrm{~mL}$ of acidified electrolyte solution and the auxiliary electrode. The two compartments were separated by a membrane, and joined by a salt bridge with a high concentration of electrolyte in the cell, $1 \mathrm{~mol} \mathrm{~L}^{-1}$.

The electrochemical studies were carried out in a potentiostat-galvanostat, VoltaLab brand, model PGN 301.

In order to determine the metal recovery yield, $10 \mathrm{~mL}$ samples were collected every hour and quantification of the metals in the samples was performed by atomic absorption spectroscopy, using a Philips apparatus, model PYE UNICAM SP9. The phase identification of the metallic deposits over the cathode and/or anode was obtained by X-ray diffraction (XRD), using a Rigaku X-ray diffractometer model DMAXIII / $\mathrm{C}$ with $\mathrm{Cu} \mathrm{K}$ radiation $(\lambda=0.15406 \mathrm{~nm})$ and working at $30 \mathrm{kV} / 40 \mathrm{~mA}$. The diffraction patterns were collected in the range of $2 \theta=10-90^{\circ}$ with a $0.02^{\circ}$ step and an acquisition time of $2 \mathrm{~s}$ per step. Scanning electron microscopy (SEM) and spectroscopy of energy dispersion X-ray (EDS), performed with Hitachi Model S-2700/Oxford (60-74), were used to visualize the morphology of the deposits and to have its semi-quantitative chemical analysis, respectively.

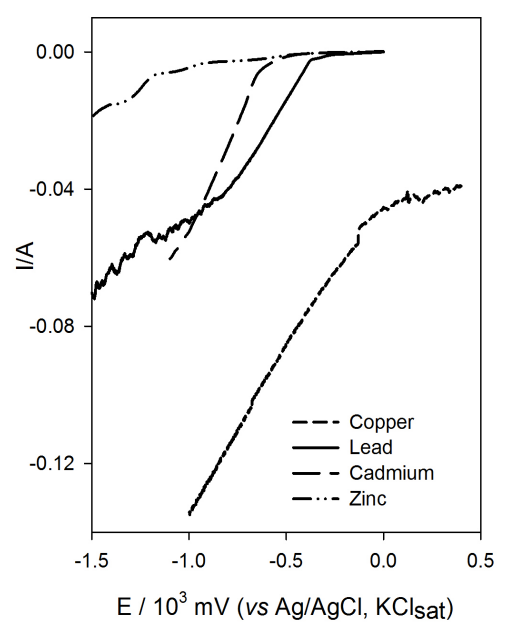

Figure 1. Voltammograms for the system $\left(1 \times 10^{-2} \mathrm{~mol} \mathrm{~L}^{-1}\right.$ metal ion $+0.035 \mathrm{~mol} \mathrm{~L}^{-1}$ electrolyte at $\mathrm{pH}=3.5$. Scan rate $20 \mathrm{mV} \mathrm{s}^{-1}$. a) $\mathrm{CuSO}_{4}$; b) $\mathrm{PbCl}_{2}$; c) $\mathrm{CdSO}_{4}$; d) $\mathrm{ZnSO}_{4}$.

\section{Results and discussion}

Voltammetric study

In order to select the applied potential for the cathodic deposition of the heavy metals in solution, linear voltammetries were run for the different solutions 
containing metal salt, at several scan rates. Fig. 1 presents the linear voltammetries performed at $20 \mathrm{mV} \mathrm{s}^{-1}$, used to determine HCP for the different metal ions, which were the following: $\mathrm{Cu}$ (II) $-100 \mathrm{mV}, \mathrm{Pb}$ (II) $-400 \mathrm{mV}, \mathrm{Cd}(\mathrm{II})$ $600 \mathrm{mV}$ and $\mathrm{Zn}$ (II) $-1000 \mathrm{mV}$.

In the linear voltammogram performed with the zinc solution some shoulders were unexpectedly found, since it was predictable that $\mathrm{Zn}$ (II) was directly reduced to the metallic phase. This observation may be explained by the existence of further reductions, related to the reduction of the sulfate to $S$ and later to $\mathrm{HS}^{-}$, species that are soluble in aqueous media [22], or a $\mathrm{Zn}^{2+}$ underpotential reduction. This has only been detected with zinc, probably because it presents a reduction potential more cathodic than the other studied metals.

\section{Removal of metals from solution by chronoamperometry}

\section{Copper}

Fig. 2, a to c, shows the micrographs obtained from deposits on the cathode at three different applied potentials, $-100,-300$ and $-500 \mathrm{mV}$, respectively, equal and more cathodic than the HCP determined for copper. Analysis of these micrographs shows a more stratified morphology for the applied potential of -100 $\mathrm{mV}$.

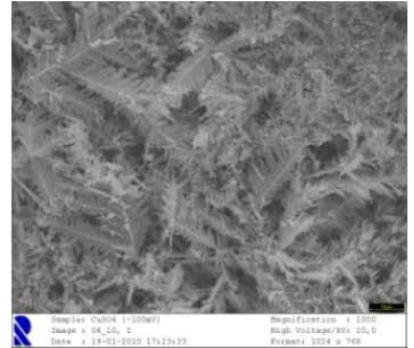

a)

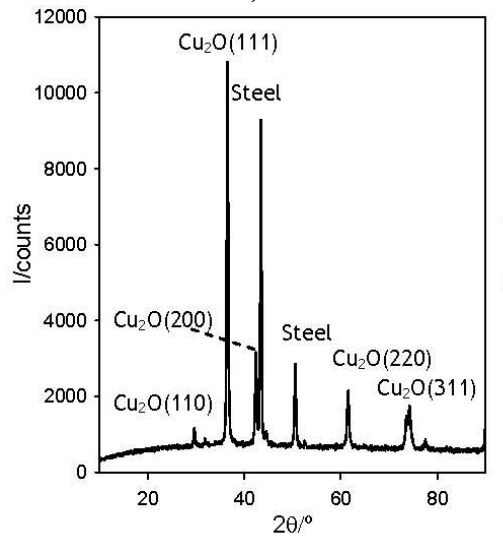

d)

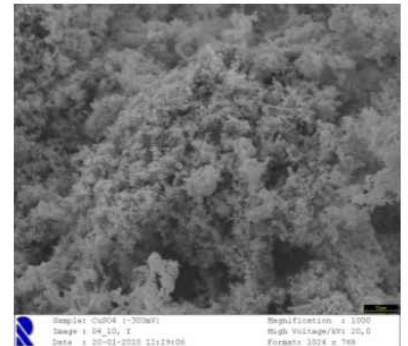

b)

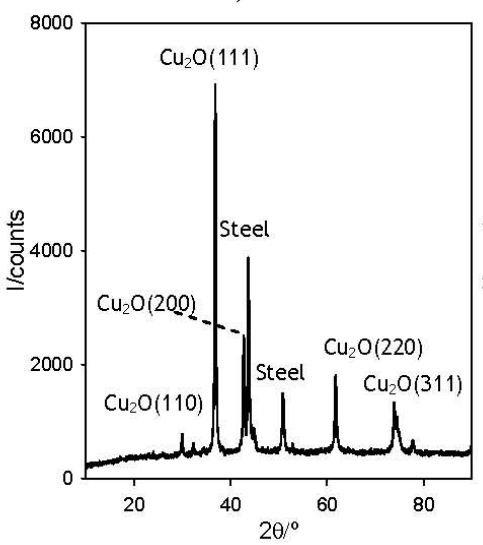

e)

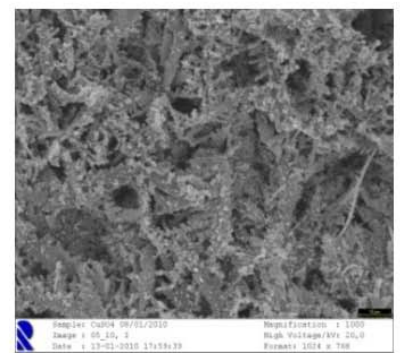

c)

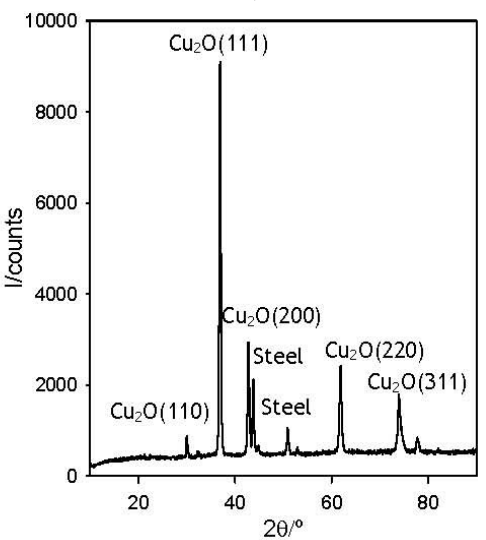

f)

Figure 2. Micrographs (magnification x1000) and X-ray diffractograms for the cathodic deposits obtained in tests run at different applied potentials with the copper sulfate solutions, in a one compartment cell: $-100 \mathrm{mV}$, a) and d); $-300 \mathrm{mV}, \mathrm{b}$ ) and e); $-500 \mathrm{mV}$, c) and f). 
The diffractograms of these deposits (Fig. 2, d to f) identified cuprite, $\mathrm{Cu}_{2} \mathrm{O}$, as the main phase, meaning that $\mathrm{Cu}$ (II) in solution was mostly reduced to $\mathrm{Cu}$ (I). The diffractograms are quite clear, with narrow peaks well defined, and when compared with XRD files from database of the Joint Committee on Powder Diffraction Standards (JCPDS) confirm that the obtained deposit was cuprite, since the experimental diffractogram coincides with that of the PDF file \# 050667 of the $\mathrm{Cu}_{2} \mathrm{O}$, cubic structure, with $\mathrm{a}=0.42696 \mathrm{~nm}$. Thus, copper (II) initially in solution was reduced to copper (I) forming the cuprite. In fact, for the applied cathodic potentials the formation of cuprite is only predictable for solutions more basic than those used [22]. However, $\mathrm{H}^{+}$reduction to $\mathrm{H}_{2}$ may compete with the reduction of $\mathrm{Cu}^{2+}$, at the cathode, increasing the local $\mathrm{pH}$ and favouring the formation of cuprite. At the end of the tests, the copper removal is almost total, being higher for the less cathodic applied potential $(-100 \mathrm{mV})$.

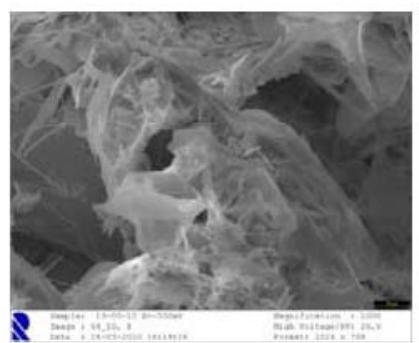

a)

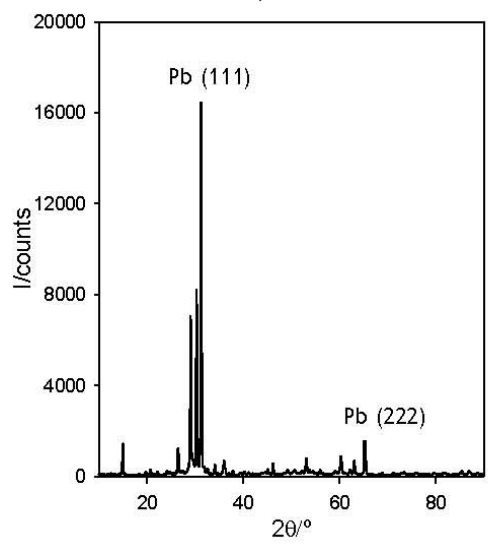

d)

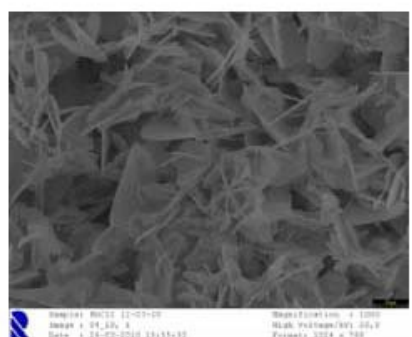

b)

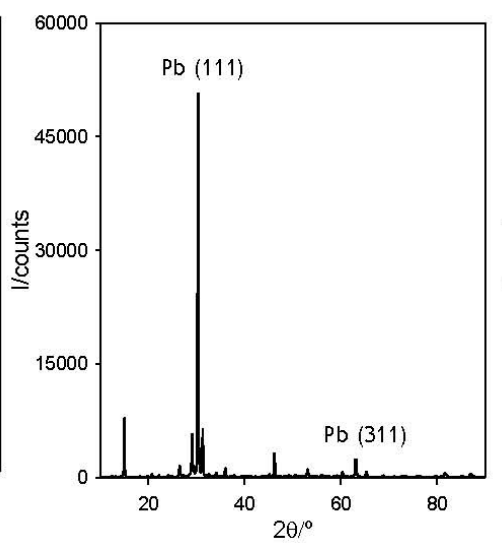

e)

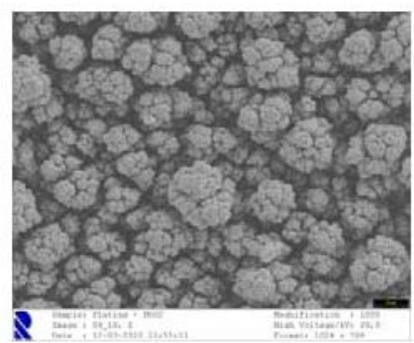

c)

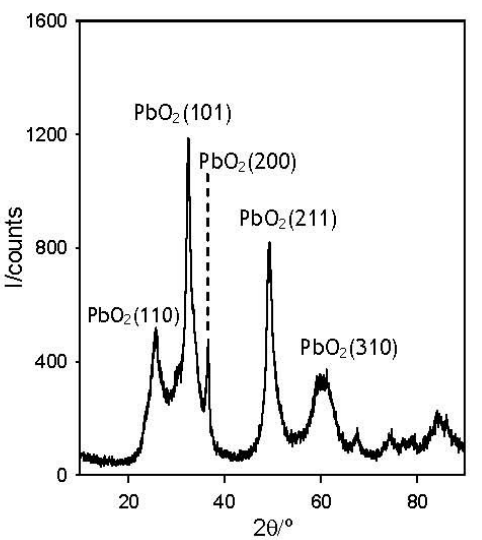

f)

Figure 3. Micrographies (magnification x1000) and XRD patterns for the deposits obtained in tests run at different applied potentials with the lead chloride solutions, in a one compartment cell: a) and d) cathodic deposit at $-500 \mathrm{mV}$; b) and e) cathodic deposit at $-800 \mathrm{mV}$; c) and f) anodic deposit at $-500 \mathrm{mV}$.

\section{$\underline{\text { Lead }}$}

Fig. 3 presents the SEM (Fig. 3a to c) and XRD (Fig. 3d to f) results for the deposits obtained for the chronoamperometries performed with lead chloride solutions, carried out in one compartment cell, at applied potentials of -500 and $800 \mathrm{mV}$. During these chronoamperometries the occurrence of a black anodic deposit was also observed, whose SEM and XRD results are also presented in Fig. 3. By analyzing the experimental diffractograms and comparing them with XRD database files, JCPDS, references (PDF \# 04-0686 for Pb and PDF \# 52- 
0751 for $\mathrm{PbO}_{2}$ ) a similarity between the values of interplanar distances points to a lead deposit over the cathode, with cubic structure and $a=0.49506 \mathrm{~nm}$, and a deposit of lead oxide over the platinum anode, with an orthorhombic structure and $\mathrm{a}=0.493 \mathrm{~nm}, \mathrm{~b}=0.4814 \mathrm{~nm}$ and $\mathrm{c}=0.3363 \mathrm{~nm}$. As the objective of this work was the recovery of metal ions in solution by cathodic reduction and in lead ion solution assays with one cell compartment, we have obtained simultaneous formation of cathodic and anodic deposits, similar tests were run in a two compartments electrochemical cell to avoid the anodic deposits. In these tests, since the anodic compartment did not contain lead ion (as described in the experimental section), only cathodic deposits were obtained, corresponding to the same $\mathrm{Pb}$ metal phase identified in the tests run in a one compartment electrochemical cell (data not shown).

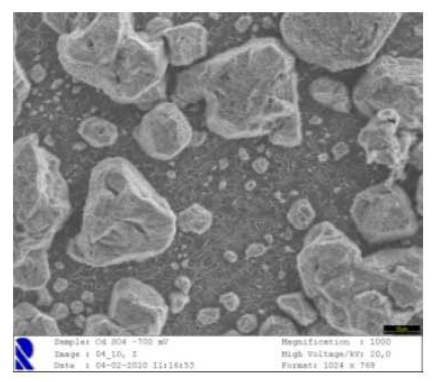

a)

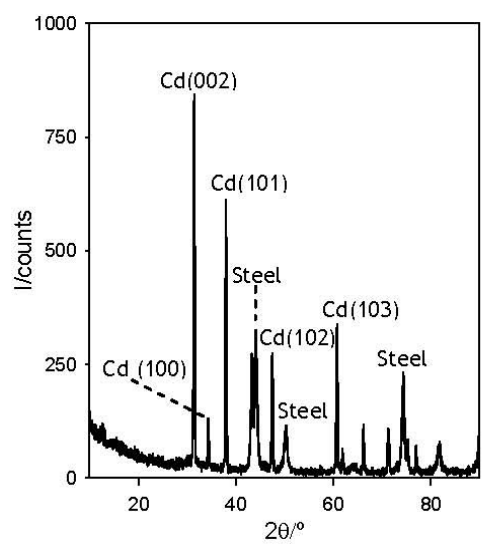

d)

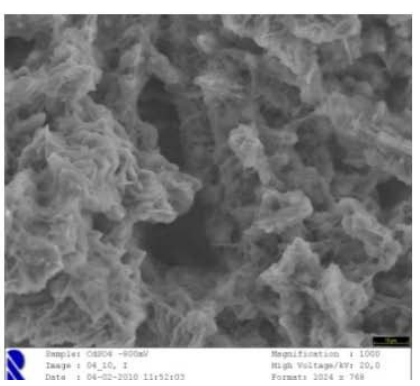

b)

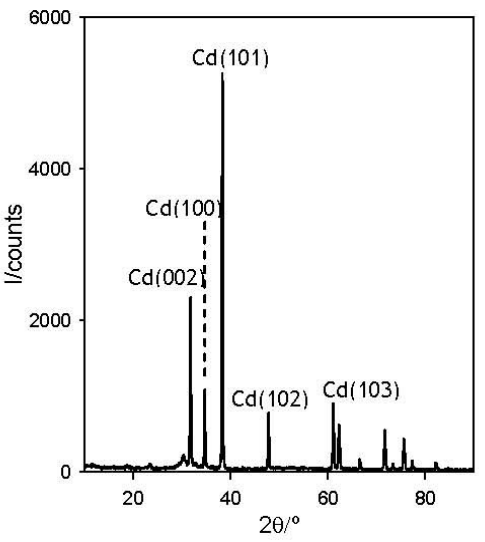

e)

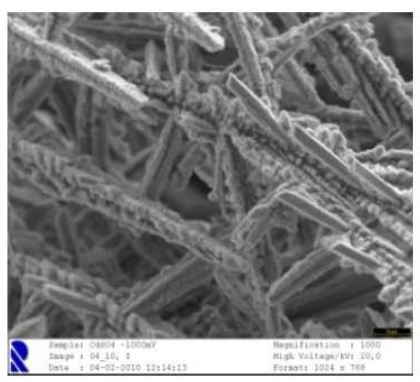

c)

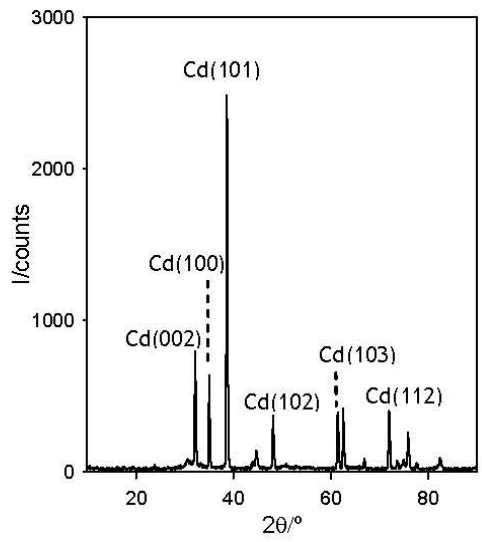

f)

Figure 4. Micrographies (magnification x1000) and XRD patterns for the cathodic deposits obtained in tests run at different applied potentials with the cadmium sulfate solutions, in a one compartment cell, at different applied potentials: $-700 \mathrm{mV}$, a) and d); $-800 \mathrm{mV}, \mathrm{b}$ ) and e); $-900 \mathrm{mV}, \mathrm{c}$ ) and f).

\section{$\underline{\text { Cadmium }}$}

Fig. 4 shows the micrographs and XRD patterns of the cathodic deposits obtained with the chronoamperometries performed with cadmium sulfate solutions at three different applied potentials: $-700,-800$ and $-900 \mathrm{mV}$. For the applied potential of -900 $\mathrm{mV}$ a more stratified morphology can be observed. Regarding the diffractograms, when a comparison with the database JCPDS files is made, the presence of cadmium metal for the three deposits can be identified, coinciding 
with the PDF file \#05-0674, showing a hexagonal structure, with $\mathrm{a}=0.2979 \mathrm{~nm}$, $\mathrm{b}=0.2979 \mathrm{~nm}, \mathrm{c}=0.5618 \mathrm{~nm}, \alpha=\beta=90^{\circ}$ and $\gamma=120^{\circ}$.

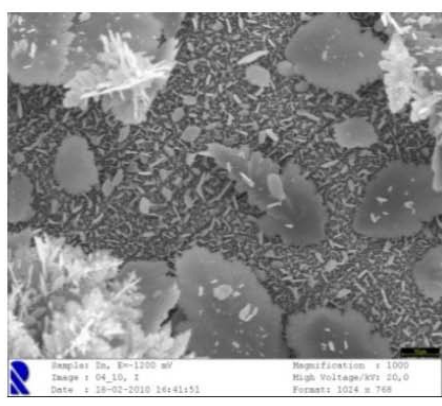

a)

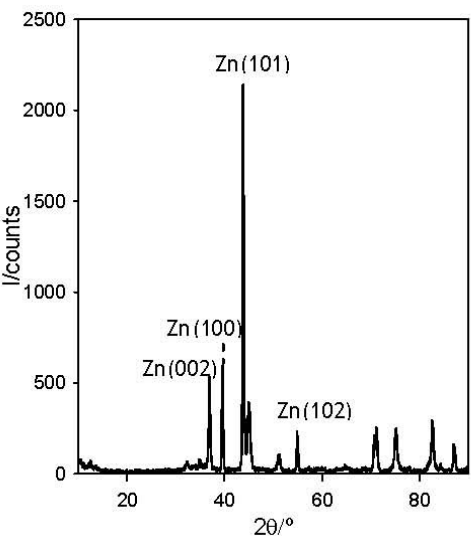

d)

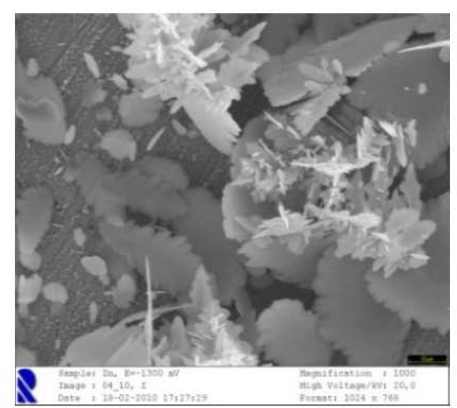

b)

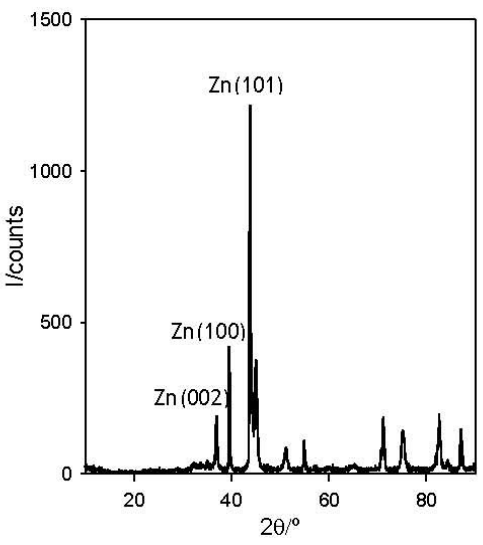

e)

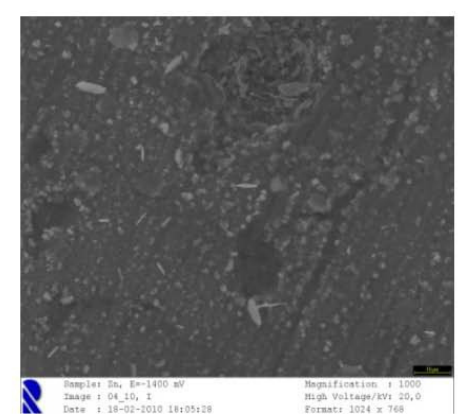

c)

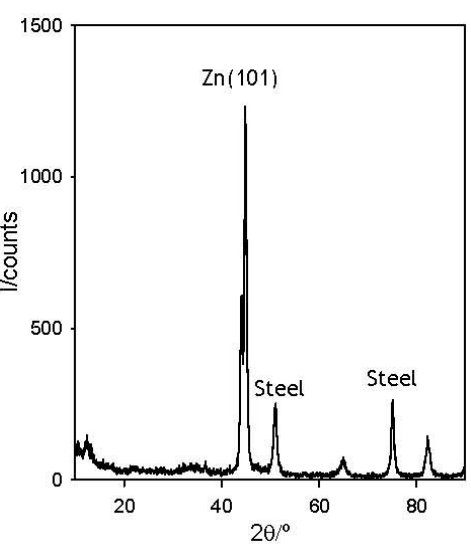

f)

Figure 5. Micrographies (magnification x1000) and XRD patterns for the cathodic deposits obtained in tests run at different applied potentials with the zinc sulfate solutions, in a one compartment cell, at different applied potentials: $-1200 \mathrm{mV}$, a) and d), $-1300 \mathrm{mV}, \mathrm{b}$ ) and e); $-1400 \mathrm{mV}, \mathrm{c}$ ) and f).

$\underline{\text { Zinc }}$

Fig. 5, a to c, shows the micrographs of the deposits obtained on the steel cathodes, for the three different applied potentials (-1200, -1300 and $-1400 \mathrm{mV})$, showing a morphology less defined for the more cathodic potential studied ($1400 \mathrm{mV}$ ). Fig. 5 also presents the diffractogram of the deposits and, when the results are compared with those from JCPDS XRD database files, one can come to the conclusion that the deposit obtained is metal zinc, since the diffractogram match the PDF file \# 04-0831, for hexagonal structure, with $a=0.2665 \mathrm{~nm}, \mathrm{~b}=$ $0.2665 \mathrm{~nm}, \mathrm{c}=0.4947 \mathrm{~nm}, \alpha=\beta=90^{\circ}$ and $\gamma=120^{\circ}$. For the highest cathodic applied potential, $-1400 \mathrm{mV}$, some refraction lines attributed to steel were detected. These lines have also been observed in some of the metal recoveries performed with copper and cadmium solutions. They were not detected in the diffractograms obtained for zinc recovery at higher applied potentials, probably due to the increase in zinc deposit obtained at less cathodic potentials that covers the substrate in a more regular way.

Table 1 shows the metal removals from solution obtained after 3 hour assays for the various applied potentials, for solutions containing a single heavy metal. 
Table 1. Percentage of removal of the various metal ions, $\mathrm{Cu}^{2+}, \mathrm{Pb}^{2+}, \mathrm{Cd}^{2+}$ and $\mathrm{Zn}^{2+}$, by chronoamperometry performed at the different applied potentials in a one compartment electrochemical cell.

\begin{tabular}{|c|c|c|c|c|c|c|c|c|c|c|c|c|}
\hline Metal & & $\mathrm{Cu}^{2+}$ & & & $\mathrm{Pb}^{2}$ & & & $\mathrm{Cd}^{2+}$ & & & $\mathrm{Zn}^{2}$ & \\
\hline $\begin{array}{l}\text { potential } \\
/ \mathrm{mV}\end{array}$ & -100 & -300 & -500 & -500 & -650 & -800 & -700 & -800 & -900 & -1200 & -1300 & -1400 \\
\hline$\%$ removal & 99 & 97 & 97 & 86 & $35^{*}$ & $\begin{array}{c}99 \\
32 *\end{array}$ & 29 & 65 & 93 & 31 & 38 & 31 \\
\hline
\end{tabular}

* Results obtained in an electrochemical cell with two compartments.

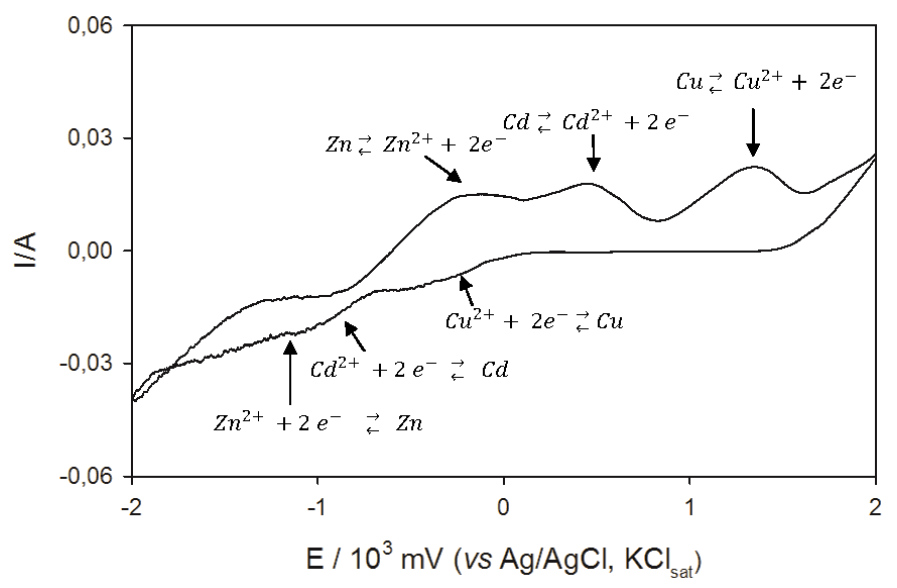

Figure 6. Cyclic voltammetry performed with the solution containing a mixture of the four metal ions, $\left[\mathrm{Cu}^{2+}\right]=\left[\mathrm{Cd}^{2+}\right]=\left[\mathrm{Zn}^{2+}\right]=0.01 \mathrm{~mol} \mathrm{~L}^{-1}$ and $\left[\mathrm{Pb}^{2+}\right]=1.4 \times 10^{-5} \mathrm{~mol} \mathrm{~L}^{-1}$, in $0.035 \mathrm{~mol} \mathrm{~L}^{-1} \mathrm{Na}_{2} \mathrm{SO}_{4}$ electrolyte at $\mathrm{pH}=3.5$, at a scan rate of $25 \mathrm{mV} \mathrm{s}^{-1}$.

\section{Mixed solution with four heavy metals}

During the preparation of the aqueous solution containing sulfates of copper (II), cadmium (II) and zinc (II) and chloride of lead (II), in a concentration of 0.01 mol L $\mathrm{L}^{-1}$ each, and $0.035 \mathrm{~mol} \mathrm{~L}^{-1}$ sodium sulphate, the formation of a precipitate of lead sulfate (Solubility of $1.4 \times 10^{-5} \mathrm{~mol} \mathrm{~L}^{-1}$ at $25^{\circ} \mathrm{C}$ [23]) occurred. After several hours stirring, the suspension was filtered and with the resulting solution a cyclic voltammetry was performed, at a scan rate of $25 \mathrm{mV} \mathrm{s}^{-1}$, starting at $2000 \mathrm{mV}$ (Fig. 6). Several successive reductions were observed in the cathodic scan, as well as several oxidations in a row in the anodic sweep. These peaks were assigned to the redox processes related with three of the four heavy metals in solution (Fig. 6) according to the sequence of the standard reduction potential. Despite the lead ion should also undergo reduction and oxidation, as its concentration is much lower than that of the other metals in solution, its redox processes are hidden between those of copper and cadmium.

Fig. 7 shows the successive chronoamperometries for the mixed solution, performed at the different chosen applied potentials, in $3 \mathrm{~h}$ periods each. Although this experiment was held in a one compartment cell, there was no black deposit of $\mathrm{PbO}_{2}$ on the anode. This may be due to the fact that lead concentration in solution was very low. In the analysis by EDX of the cathode deposits it was not possible to identify lead, probably due to the same reasons. 


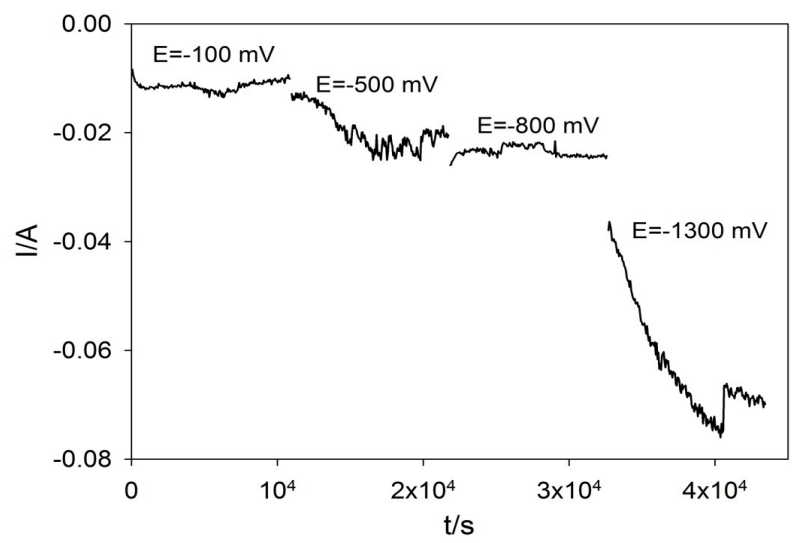

Figure 7. Successive chronoamperometries, with $3 \mathrm{~h}$ each, performed with the mixed solution containing the four ion metals, $\left[\mathrm{Cu}^{2+}\right]=\left[\mathrm{Cd}^{2+}\right]=\left[\mathrm{Zn}^{2+}\right]=0.01 \mathrm{~mol} \mathrm{~L}^{-1}$ and $\left[\mathrm{Pb}^{2+}\right]=1.4 \times 10^{-5} \mathrm{~mol} \mathrm{~L} 1$, in $0.035 \mathrm{~mol} \mathrm{~L}^{-1} \mathrm{Na}_{2} \mathrm{SO}_{4}$ electrolyte at $\mathrm{pH}=3.5$, at the different applied potentials: $-100,-500,-800$ and $-1300 \mathrm{mV}$.

Table 2. Percentage of removal of metal ions $\mathrm{Cu}^{2+}, \mathrm{Pb}^{2+}, \mathrm{Cd}^{2+}$ and $\mathrm{Zn}^{2+}$ from the solution containing the four heavy metals after consecutive chronoamperometries, of $3 \mathrm{~h}$ each, performed at four distinct potentials, in a one compartment electrochemical cell.

\begin{tabular}{ccccc}
\hline & \multicolumn{5}{c}{ Metal \% of removal from solution } \\
\cline { 2 - 5 } Metal & \multicolumn{4}{c}{ Applied potential / $\mathbf{~ V}$} \\
\cline { 2 - 5 } & $\mathbf{- 1 0 0}$ & $\mathbf{- 5 0 0}$ & $\mathbf{- 8 0 0}$ & $\mathbf{- 1 3 0 0}$ \\
\hline $\mathrm{Cu}^{2+}$ & 55 & 70 & 93 & 99 \\
\hline $\mathrm{Pb}^{2+}$ & - & 38 & 56 & 68 \\
\hline $\mathrm{Cd}^{2+}$ & - & - & 20 & 92 \\
\hline $\mathrm{Zn}^{2+}$ & - & - & - & 10 \\
\hline
\end{tabular}

The metal removals from solution during the successive chronoamperometries are presented in Table 2 and, with the exception of zinc, good removals were obtained at the end. The XRD analysis of the cathodes allowed the conclusion that heavy metals were recovered in metallic form, even for copper, which, when isolated in solution, was recovered in the form of cuprite.

Comparing the values of removals obtained in the individual test, after 3 hours, with the values obtained in the mixed solution, it appears that removal is greater when the metal is "isolated". The worst removal values have been obtained for zinc in both situations, due to the high formation of hydrogen even at its HCP.

\section{Conclusions}

The recovery of copper from solution presented different behaviors for solutions containing just $\mathrm{Cu}^{2+}$ or a mixture of $\mathrm{Cu}^{2+}$ with other metal ions, at the same applied potential and with the same experimental setup: in the former case, copper was recovered by reduction on the cathode in the form of $\mathrm{Cu}_{2} \mathrm{O}$ and, in the later case, it was deposited over the cathode has metallic copper.

Regarding $\mathrm{Pb}^{2+}$ removal from aqueous solutions, it was recovered in the metallic form over the cathode and in the form of $\mathrm{PbO}_{2}$ over the anode, when tests were 
run in a one compartment cell. However, when the assay was performed in a two compartments cell, with the metal ion only in the cathodic solution, lead was recovered in the metallic form over the cathode, avoiding anodic deposit. The removal of lead ion from solution in the cell with two compartments was significantly lower than that obtained in a one compartment cell.

Metal ions $\mathrm{Cd}^{2+}$ and $\mathrm{Zn}^{2+}$ were recovered in the metallic form over the cathode, in a one compartment cell, either from the solutions containing just a single metal ion or when solutions containing a mixture of metal ions were used.

The best results obtained in the recovery of the different metals, obtained in a one compartment cell, after $3 \mathrm{~h}$ under the applied experimental conditions, for solutions containing just one metal ion, were: $\mathrm{Cu}^{2+} 99 \%$ at $\mathrm{E}=-100 \mathrm{mV} ; \mathrm{Pb}^{2+}$ $99 \%$ at $\mathrm{E}=-800 \mathrm{mV} ; \mathrm{Cd}^{2+} 93 \%$ at $\mathrm{E}=-800 \mathrm{mV}$ and $\mathrm{Zn}^{2+} 38 \%$ at $\mathrm{E}=-1300 \mathrm{mV}$. The low yield observed for zinc is related to the fact that its reduction is given under conditions where the release of hydrogen is quite intense and there is competition between the two reduction processes.

The duration of the experiments containing single metal ion was adequate for the almost total removal of metals from solutions, with the exception made to zinc ion solutions. In the case of the mixed solutions, with four metal ions, the four consecutive runs, with $3 \mathrm{~h}$ each, at selected potentials, proved to be enough to achieve high removals of the various metals, exception made for zinc: $99 \%$ for $\mathrm{Cu}^{2+}, 68 \%$ for $\mathrm{Pb}^{2+}, 92 \%$ for $\mathrm{Cd}^{2+}$ and $10 \%$ for $\mathrm{Zn}^{2+}$.

\section{Acknowledgements}

Fundação para a Ciência e a Tecnologia, FCT, PTDC/AAC-AMB/103112/2008.

\section{References}

1. A. Fuentes, M. Lloréns, J. Sáez, M.I. Aguilar, A.B. Pérez-Marín, J.F. Ortuño, V.F. Meseguer, Environ. Pollut. 143 (2006) 355-360.

2. F. Hammy, G. Mercier, J-F. Blais, Hydrometallurgy 80 (2005) 232-240.

3. A. Janin, F. Zaviska, P. Drogui, J-F. Blais, G. Mercier, Hydrometallurgy 96 (2009) 318-326.

4. V. Cinanni, I.A. Gough, A.J. Sciuto, Desalination 106 (1996) 145-150.

5. M. Hunsom,_K. Pruksathorn, S. Damronglerd, H. Vergnesb, P. Duverneuil, Water Res. 39 (2005) 610-616.

6. N.M.S. Kaminari, D.R. Schultz, M.J.J.S. Ponte, H.A. Ponte, C.E.B. Marino, A.C. Neto, Chem. Eng. J. 126 (2007) 139-146.

7. V.G. Lacerda, A.B. Mageste, I.J.B. Santos, L.H.M. Silva, M.C.H. Silva, J. Power Sources 193 (2009) 908-913.

8. C.A. Basha, N.S. Bhadrinarayana, N. Anantharaman, K.M.M.S. Begum, J. Hazard. Mater. 152 (2008) 71-78.

9. L. Doulakas, K. Novy, S. Stucki, Ch. Comninellis, Electrochim. Acta 46 (2000), 349-356.

10. M.C. Santos, S.A.S. Machado, L.A. Avaca, L.H. Mascaro, Quím. Nova 23 (2000) 392-400. 
11. R.Y. Bek, V.N. Kiryushov, L.I. Skvortsova, T.P. Aleksandrova, V.A. Tarasova, J. Anal. Chem. 55 (2000) 1069-1073. (Translated from Zhurnal Analiticheskoi Khimih), 55 (2000) 1190-1194.

12. J.P. Chen, L.L. Lim, Chemosphere 60 (2005) 1384-1392.

13. D. Arrington, M. Curry, S. Street, G. Pattanaik, G. Zangary, Electrochim. Acta 53 (2008) 2644-2649.

14. K.I. Popov, T.M. Kostic, N.D. Nikolic, E.R. Stojilkovic, M.G. Pavlovic, J. Electroanal. Chem. 464 (1999) 245-251.

15. K.I. Popov, P.M. Zivkovic, S.B. Krstic, N.D. Nikolic, Electrochim. Acta 54 (2009) 2924-2931.

16. C-C. Yang, J. Power Sources 115 (2003) 352-359.

17. R. Mayén-Mondragón, J.G. Ibanez; R.C. Vasquez; A. Baeza, M.T. Oropeza, Water Air Soil Poll. 194 (2008) 45-55.

18. F-R. Xiu, F-S. Zhang, J. Hazard. Mater. 170 (2009) 191-196.

19. N.P. Brandon, D. Pilone, G.H. Kelsall, Q. Yin, J. Appl. Electrochem. 33 (2003) 853-862.

20. K. Scott, X. Chen, J.W. Atkinson, M. Todd, Resources, Conserv. Recycling 20 (1997) 43-55.

21. D. Pilone, G.H. Kelsall, Electrochim. Acta 51 (2006) 3802-3808.

22. M. Pourbaix, Atlas D'équilibres Électrochimiques à $25^{\circ} \mathrm{C}, 1^{\text {ere }} \mathrm{Ed}$., Gauthier-Villars \& Cie Éditeur, Paris, 1963.

23. Handbook of Chemistry and Physics, CRC Press, Inc, Florida, $63^{\text {rd }}$ Ed., 1982-1983. 